\title{
The Effects of Some Essential Oils Against Nosemosis
}

\author{
Fatih Yılmaz $^{1, *}\left(\mathbb{D}\right.$, Ahmet Kuvancı $^{1}\left(\mathbb{D}\right.$, Feyzullah Konak ${ }^{1}(\mathbb{D})$, S. Hasan Öztürk ${ }^{1}(\mathbb{D}$, \\ A. Emir Şahin ${ }^{1}$
}

${ }^{1}$ Apiculture Research Institute, Ordu, Turkey

\section{Article History}

Received 19 June 2020

Accepted 28 December 2020

First Online 28 December 2020

\section{* Corresponding Author \\ Tel.: +905325514184 \\ E-mail: fatihyilmaz@hotmail.com}

\author{
Keywords \\ Honey bee \\ Nosema \\ Thyme \\ Garlic \\ Supplementary feeding
}

\begin{abstract}
Nosema is an important disease that negatively affects bees' performance by disrupting the digestive system of bees. The disease, which is known to be widespread in almost every part of the world except Central Africa, is a highly dangerous fungal infection for honey bees, which occurs with infection of honey bees' ventricular epithelial cells by Nosema apis and Nosema ceranae. Nosema infection, one of the most common diseases in honey bees, is more dangerous due to the adverse effects of the factor itself and secondary infections. It is one of the most important causes of honey bee colony losses. This study aimed to investigate the effectiveness levels of essential etheric oils against nosema infection. 21 colonies obtained from Ordu Region, equalized physiologically and divided into 7 groups. Nettle, laurel, eucalyptus, thyme, garlic oils (after dilution of $0.48 \%$ ), and apple cider vinegar were given to each colony 6 times at 3 days intervals of $3 \mathrm{~mL} / \mathrm{L}$ to $1: 1$ ratio syrup (prepared for each separate group). Adult bee samples were taken from all colonies before each additional feeding, and nosema spore counts were performed.
\end{abstract}

\section{Introduction}

Nosematosis, the important bee diseases, is seen as one of the main causes of colony losses and reduces the adult bee population with the intensive detection of Nosema ceranae in recent years. The disease could be acute or chronic, and colony losses vary between 10 $100 \%$ depending on environmental conditions. Indigestion, abdominal bloating, shortened lifespan, and inability to fly with open wings, change of queen and eggs, yellow-brown foul-smelling, dark-coloured stool are seen in sick bees. The decrease in the colony population and honey yield, and colony losses can be seen (Morse \& Flottum. 1997).

Bees infected with $N$. apis survive 18-54 days in sudden colony extinction, while those infected with $N$. ceranae die within 8-10 days. Nosemosis has been identified by microscopic examination in $60 \%$ of the apiary in Turkey, $14 \%$ of colonies were found infected in these apiaries, and clinical symptoms were determined in $14 \%$ of infected colonies (Muz, 2008).

$N$. apis and $N$. ceranae cannot be distinguished by microscopic examinations used in routine research; separating these two factors by molecular genetic methods is possible (Uygur \& Girişgin, 2008).

In most 1260 samples taken from 420 enterprises belonging to the Beekeepers of the Eastern Black Sea Region (infection rate found $89 \%$ in spring and $38 \%$ in autumn), nosema spores were encountered. It is important to consider that seriously; nosema spores were encountered in the autumn period. While Nosema ceranae was detected in all the positive samples collected in the spring and autumn periods, Nosema apis was not encountered (Yılmaz et al., 2018).

Essential oils, also known as volatile oils, are aromatic fatty compounds obtained from different parts 
of plants (flowers, buds, seeds, leaves, branches, bark, wood, fruit, and roots). These natural products are widely used in various fields, including perfume, cosmetics, aromatherapy, phytotherapy, spices, nutrition, and agriculture. The biological activities of essential oils, including antibacterial, antiviral, antifungal, and anti-inflammatory effects, are well known. These oils can also be effective against organisms such as nematodes, helminths, and insects. Essential oils are known by different names, such as volatile oil, etheric oil, scented oil, or essence oil (Şengezer \& Göngör, 2008).

Observing the antimicrobial effect, even in a microorganism, has shown that plants containing etheric oil can be used for therapeutic purposes and may be an alternative to synthetic antibiotics (Benli \& Yiğit, 2005).

In recent years, the emergence of antibioticresistant microorganisms and being side effects not seen or seen less in natural medicines, which synthetic drugs have, led scientists to investigate natural-based treatments (Dürger, Ceyhan, Alitsaous, \& Uğurlu, 1999).

Maistrello et al. (2008) evaluated the effects of some natural compounds (thymol, vetiver essential oil, lysozyme, and resveratrol) on Nosema ceranae spore infected honey bees by cage trials. Infected bees were given sugar solutions containing thymol $0.12 \mathrm{mg} / \mathrm{g}$, lysozyme $2.5 \mathrm{mg} / \mathrm{g}$, vetiver essential oil $1.2 \mathrm{mg} / \mathrm{g}$, resveratrol $0.001 \mathrm{mg} / \mathrm{g}$, and ethanol as a control group in the study. On the 8th day, 2.6 million spores/bees were detected in the control group, while on the 25th day, this number was determined as $\mathbf{2 3 0}$ million spores/ bees. Honey bees fed diets containing thymol, vetiver essential oil, lysozyme, and resveratrol; on the 8th day, 2.46 million spores/bees, 1.37 million spores/ bees, 1.87 million spores/bees, and 3.3 million spores/bees were identified, respectively. On the 25th day, 20.0 million spores/bees in the thymol group, 144.5 million spores/bees in the vetiver essential oil group, 54 million spores/bees in the resveratrol group were identified, and all bees of the lysosome group died. As a result, it was emphasized that the infection rates of bees fed with sugar solutions containing thymol and resveratrol decreased significantly and may be useful in alternative strategies for controlling nosema disease.

In the in-vitro study, in which Costa, Lodesani, and Maistrello (2009) evaluated the effects of thymol and resveratrol on the growth of Nosema ceranae and lifetime of honey bees, $100 \mathrm{ppm}$ thymol and $10 \mathrm{ppm}$ resveratrol were given to honey bees infected with of Nosema ceranae spore by adding $50 \%$ sucrose. The nosema spore numbers of honey bees fed with sugar solutions containing control, thymol, and resveratrol were counted as 2.0 million spores/bees, 1.7 million spores/bees, and 1.3 million spores/bees on the 8th day; 118.1 million spores/bees; 60.0 million spores/bees and 126.2 million spores/bees on the 25th day, respectively. On day 25 of the study, it is determined that bees fed with thymol syrup had significantly lower infection levels than control group bees, and bees fed thymol or resveratrol syrup were significantly live longer (23 and 25 days, respectively) than control group bees ( 20 days). Syrup, specially treated with thymol, has been reported to be promising in the control of nosema infection.

The activity of plant extracts on the development of Nosema ceranae was studied by Porrini et al. (2011). Honey bees were infected with nosema spores under laboratory conditions. Infected bees were fed ad libitum with enriched syrups. Diets in the feed of bees were created from ethanolic extracts from Artemisia absinthium, Allium sativum, Laurus nobilis, and Ilex paraguariensis diluted in syrup concentrations of $1 \%$ and $10 \%$. On the 19th day after infection, it showed that the concentration of $1 \%$ L. nobilis extract significantly inhibited $N$. ceranae.

This study aimed to investigate the effectiveness levels of essential etheric oils against nosema infection.

\section{Materials and Methods}

21 colonies were obtained from Ordu Region in May 2019, and they were divided into 7 groups after equalization, one of which was a control group in 3 colonies. Application groups have been formed with nettle (Urtica dioica), laurel (Cucurbita pepo), eucalyptus (Eucalyptus globulus), thyme (Thymus vulgaris), garlic (Allium sativum) oils, and apple cider vinegar. All the essential oils were in a $20 \mathrm{~mL}$ bottle, purchased from the same brand produced in Turkey, and stored in appropriate conditions. Apple cider vinegar and essential oils were added to the syrup at a ratio of 1: $1,3 \mathrm{~mL} / \mathrm{L}$, and given $1 \mathrm{~L}$ to each colony, 6 times with an interval of 3 days. The essential oil and syrup mixture were prepared daily. The oils belonging to the application groups were added to the syrup after $0.48 \%$ dilution. Only sugar syrup was given to the control group. Before each additional feeding, 10 worker bee samples were taken from each of the colonies, and nosema spore counts were performed.

\section{Native Examination}

By taking the abdominal intestine of 10 adult bees from each colony; Crushed in mortar in 2-3 ml saline. The native examination was performed under a light microscope with a $40 \mathrm{X}$ magnification after the suspension of the obtained bees obtained from adult bees on a lame with a lamella (Anonymous, 2005; Anonymous, 2009; Zeybek, 1991).

\section{Staining Examination}

After the samples prepared in physiological saline solution were air-dried and determined with ethanol, staining of spores was performed when stained with Giemsa for 45 minutes (Anonymous, 2009; Beyazıt et al., 2012). 


\section{Nosema Spores Counting}

Samples were examined under a microscope, and spores counts (Shimanuki \& Knox, 2000) were made from 20 bees of positive samples with nosema infection. At least 20 alive or dead bees suspicious of the disease were taken and kept in a container containing $70 \%$ alcohol for 1 day. The received bees were taken individually on a suitable ground (wood), and the abdomen was separated with the help of a scalpel. The cut abdomen was placed in a glass homogenizer or a suitable tube. A milliliter of water for each abdomen (20 $\mathrm{mL}$ of water for 20 abdomens) was added to the container. This mixture was thoroughly crushed with a rammer in a container. It was filtered with a filter paper to another container, filtered liquid mixed with a pipette and a drop placed to a lame, examined in a 40 lens after covering with lamella.

For the spores count, 5 large squares in the counting area of the 40 lenses were counted after the suspicious liquid was placed with a pipette to cover the Thoma slide area (a, b, c, d, e) (Figure 3). The total

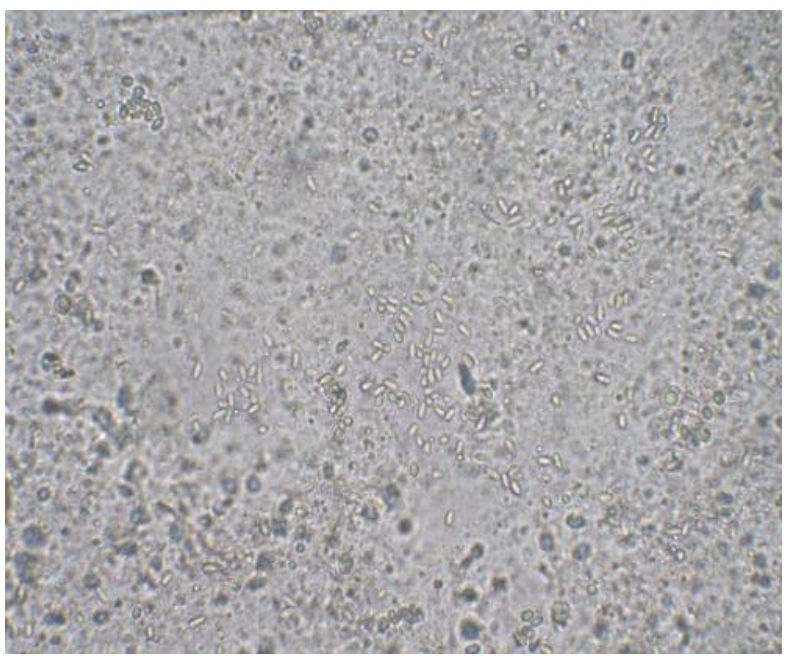

Figure 1. Native examination.

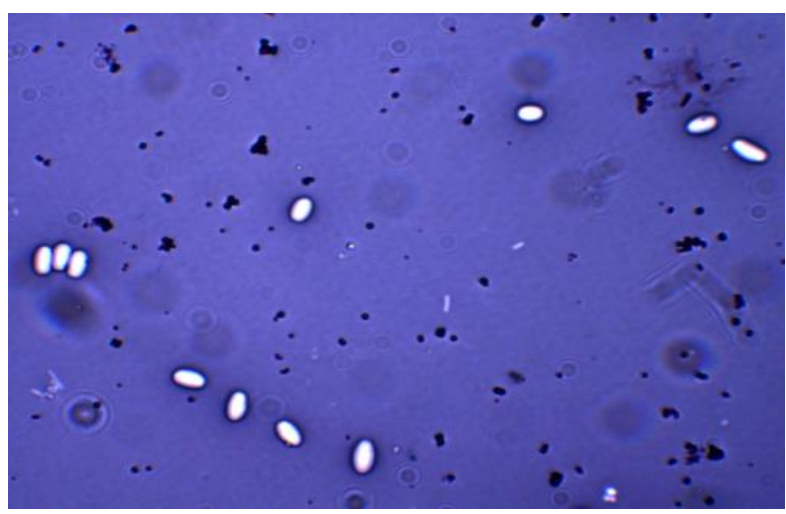

Figure 2. Colourization by examination. number of spores (S) applies to the formula: The number of spores per bee $(N)=S \times 4 \times 106 / 80$ by replacing the number in the formula, the number of spores per bee was calculated.

\section{Results}

The intragroup normality assumption of the data was analyzed with the Shapiro Wilk test, and it was determined that the data were normally distributed $(P>$ $0.05)$. Therefore, the data analysis was made according to the two-way analysis of variance in repeated measurements. Since Mauchly's sphericity test provides assumptions $(P=0.36)$, the results were examined according to the Sphericity assumption test.

The effect of the Essential oils and Essential oils $x$ application time interactions were found insignificant. Since the difference between the application times was significant, comparisons were made according to Bonferroni test. SPSS package program was used to analyses of the data.

Boland, Fro, and Lorenz (1991) stated that the components found in plant oils such as eucalyptus, lemon extract, and thyme are effective against fungi.

It has been observed that the nosema spores in the application and control groups decreased significantly in the 3 weeks since the beginning of the study. The decreasing tendency was also decelerated in the 4th and 5th weeks (Table 1 ).

The importance of protective measures in beekeeping is revealed by the absence of a chemical drug against nosema, the desired result from alternative treatment methods, and the tendency of nosema infection in the control group to fall before the main nectar flow. By providing good ventilation of colonies against nosema infection, the formation of a moist environment that causes spores' proliferation can be prevented. Better results can be obtained with proper care and feeding activities. Colonies were observed during the essential oil trials, and no abnormal deaths were observed in any colonies.

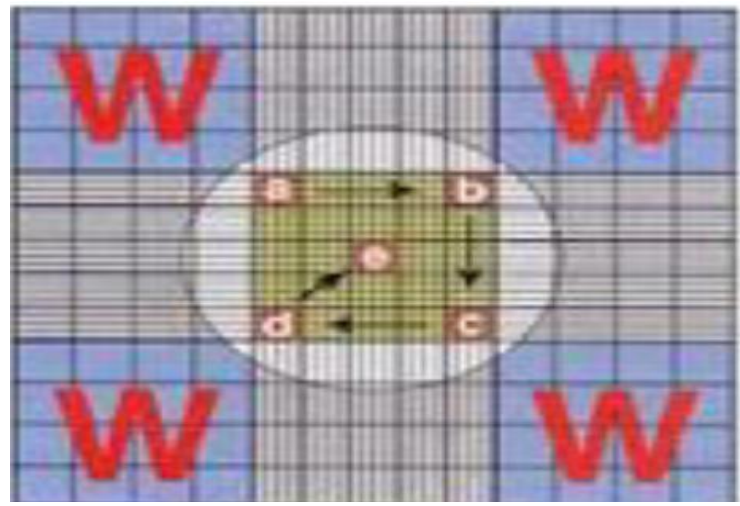

Figure 3. Nosema spores counting area 


\section{Discussion}

As seen in Figure 4, spores' density in the control group and other groups decreased gradually after the four applications with an interval of 3 days, in the colonies emerging from the spring. In later measurements, the laurel and the control groups were constant. Simultaneously, an undesirable increase was observed in the thyme and eucalyptus, whereas there was a partial decrease in nettle, especially garlic.

Based on the findings here, it is thought that nosema spores can progress in the form of a spontaneous increase or decrease depending on the season and climate conditions.

Although the essential oils used in thyme and eucalyptus showed a better decrease in the first four applications than the control group, the tendency to increase again in the following applications suggests that this product may affect the intestinal tract flora of honey bees. Essential oils containing thyme and eucalyptus should be used in a maximum of 4 doses against Nosema infection and should not be exceeded.

Table 1. Spores intensity distribution during working time.

\begin{tabular}{|c|c|c|c|c|c|c|c|c|c|}
\hline \multirow[b]{2}{*}{$\begin{array}{l}\text { Essential } \\
\text { oils }\end{array}$} & \multicolumn{9}{|c|}{ Weeks (Average \pm SS) } \\
\hline & $\mathrm{n}$ & 1 Week & 2 Weeks & 3 Weeks & 4 Weeks & 5 Weeks & 6 Weeks & $\mathrm{n}$ & Average \pm SS \\
\hline Nettle & 3 & $\begin{array}{c}34116666.7 \pm \\
1233220.7\end{array}$ & $\begin{array}{c}30233333.3 \pm \\
7695182.5\end{array}$ & $\begin{array}{c}12300000 \pm \\
2961418.6\end{array}$ & $\begin{array}{c}8066666.7 \pm \\
2503164.7\end{array}$ & $\begin{array}{l}9100000 \pm \\
9860527.4\end{array}$ & $\begin{array}{c}7633333.3 \pm \\
5653612.4\end{array}$ & 18 & $\begin{array}{c}16908333.3 \pm \\
12295865.5\end{array}$ \\
\hline Laurel & 3 & $\begin{array}{c}28700000 \pm \\
8886928.6\end{array}$ & $\begin{array}{c}26816666.7 \pm \\
7956339.2\end{array}$ & $\begin{array}{c}17466666.7 \pm \\
3859188.2\end{array}$ & $\begin{array}{c}9516666.7 \pm \\
1841421.6\end{array}$ & $\begin{array}{l}8750000 \pm \\
3001249.7\end{array}$ & $\begin{array}{l}9100000 \pm \\
8983874.4\end{array}$ & 18 & $\begin{array}{l}16725000 \pm \\
10172183.1\end{array}$ \\
\hline Thyme & 3 & $\begin{array}{c}19416666.7 \pm \\
4365012.4\end{array}$ & $\begin{array}{c}12516666.7 \pm \\
6771693.5\end{array}$ & $\begin{array}{l}8400000 \pm \\
4411065.6\end{array}$ & $\begin{array}{c}9033333.3 \pm \\
3167149.1\end{array}$ & $\begin{array}{c}6933333.3 \pm \\
1409196\end{array}$ & $\begin{array}{c}7866666.7 \pm \\
1940575.5\end{array}$ & 18 & $\begin{array}{c}10694444.4 \pm \\
5578263.7\end{array}$ \\
\hline Ocaliptus & 3 & $\begin{array}{l}22250000 \pm \\
14104343.3\end{array}$ & $\begin{array}{c}19183333.3 \pm \\
6824465.8\end{array}$ & $\begin{array}{c}11450000 \pm \\
476969.6\end{array}$ & $\begin{array}{l}7950000 \pm \\
4036087.2\end{array}$ & $\begin{array}{c}8133333.3 \pm \\
381881.3\end{array}$ & $\begin{array}{l}9100000 \pm \\
7668278.8\end{array}$ & 18 & $\begin{array}{c}13011111.1 \pm \\
8449600.7\end{array}$ \\
\hline Garlic & 3 & $\begin{array}{c}28966666.7 \pm \\
12576797.4\end{array}$ & $\begin{array}{c}31150000 \pm \\
4130072.6\end{array}$ & $\begin{array}{c}15450000 \pm \\
3950949.3\end{array}$ & $\begin{array}{c}11500000 \pm \\
5358871.1\end{array}$ & $\begin{array}{l}6000000 \pm \\
1477328.7\end{array}$ & $\begin{array}{c}3816666.7 \pm \\
725143.7\end{array}$ & 18 & $\begin{array}{c}16147222.2 \pm \\
11990381.8\end{array}$ \\
\hline Vinegar & 3 & $\begin{array}{c}26716666.7 \pm \\
1068098\end{array}$ & $\begin{array}{c}26133333.3 \pm \\
6130320.8\end{array}$ & $\begin{array}{c}20983333.3 \pm \\
5461761\end{array}$ & $\begin{array}{c}16150000 \pm \\
5438060.3\end{array}$ & $\begin{array}{c}14900000 \pm \\
8448520.6\end{array}$ & $\begin{array}{c}11033333.3 \pm \\
7821338.3\end{array}$ & 18 & $\begin{array}{c}19319444.4 \pm \\
7925427\end{array}$ \\
\hline Control & 3 & $\begin{array}{c}26866666.7 \pm \\
10876158.9\end{array}$ & $\begin{array}{c}26750000 \pm \\
3553871.1\end{array}$ & $\begin{array}{c}18683333.3 \pm 4 \\
668065.3\end{array}$ & $\begin{array}{c}14833333.3 \pm \\
6984685.6\end{array}$ & $\begin{array}{c}10033333.3 \pm \\
5189010.8\end{array}$ & $\begin{array}{c}10250000 \pm \\
650000\end{array}$ & 18 & $\begin{array}{c}17902777.8 \pm \\
8828887.6\end{array}$ \\
\hline Variatio & 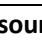 & & ant & & Time & & & t*Time & \\
\hline & & & 066 & & $<0.001$ & & & .384 & \\
\hline
\end{tabular}

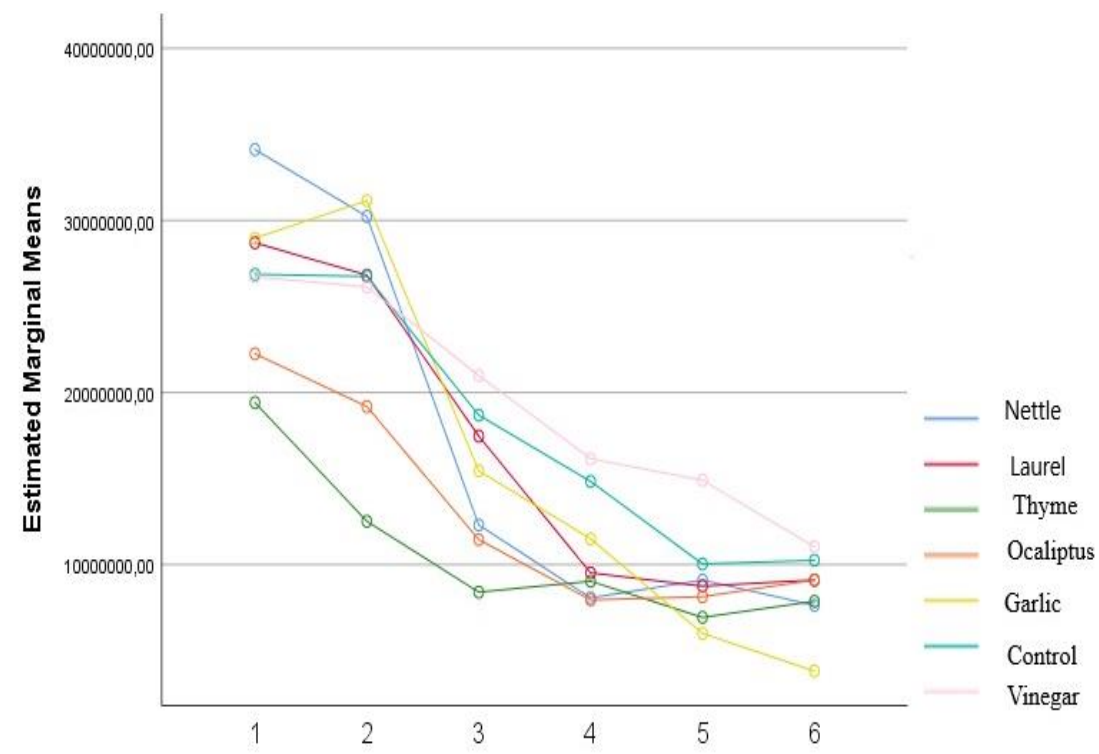

Figure 4. Spore intensity distribution after six applications of essential oils 


\section{Conclusion}

Colony losses without reason have frequently been on the agenda in recent years, and the colonial losses must be associated with Nosemosis density in colonies. Protective measures should be taken against Nosema, and studies on treatment should be emphasized.

The study has shown that the essential oils used to decrease the number of spores that cause infection, but there is no definite result for treating the disease. It has been determined that garlic oil is one of the essential oils that has shown better results, and apple cider vinegar has no effect.

Essential oils used against nosema should be applied based on scientific data to protect human and bee health. The questions on the dose and mechanism of essential oils action against nosema infestation are not clear yet; more scientific studies are needed.

\section{References}

Anonymous, (2005). Laboratory method collection. Twinning Project between Turkey and Germany, Support for the Alignment of Turkey with the EU Veterinary Acquins (Twinning No: TR02/IB/AG-01, Project No: TR 0203.05).

Anonymous, (2009). OIE Manual of diagnostic tests and vaccines for terrestrial animals. Retrieved from http://www.oie.int/eng/normes/mmanual/2008/pdf/2. 02.04_NOSEMOSIS. pdf.

Benli, M., \& Yiğit, N. (2005). Ülkemizde Yaygın Kullanımı Olan Kekik (Thymus vulgaris) Bitkisinin Antimikrobiyal Aktivitesi. Orlab On-Line Mikrobiyoloji Dergisi, 03(08), 18.

Beyazıt, A., Akkoca, N., Eskiizmirliler, S., Albayrak, H., Özan, E., Özden, M., Selver, M.M., \& Tunalıgil, S. (2012). Ege Bölgesi illerinde önemli arı hastalıklarının yaygınlığının araştırıması, Hayvan Sağlığı Program Değerlendirme Özet Kitabı, Ankara.
Boland, W., Fro, C., \& Lorenz, M. (1991). Esterolytic and lipolytic enzymes in organic synthesis. Synthesis, 12, 1049-1072.

Costa, C., Lodesani, M., \& Maistrello, L. (2010). Effect of thymol and resveratrol administered with candy or syrup on the development of Nosema ceranae and on the longevity of honeybees (Apis mellifera L.) in laboratory conditions. Apidologie, 41, 141-150.

Dürger, B., Ceyhan, M., Alitsaous, M., \& Uğurlu, E. (1999). Artemisia absinthium L. (Pelin)'un Antimikrobiyal Aktivitesi. Turkish Journal of Biology, 23(3), 377-384.

Maistrello, L., Lodesani, M., Costa, C., Leonardi, F., Marani, G., Caldon, M., Mutinelli, F., \& Granato, A. (2008). screening of natural compounds for the control of nosemadisease in honeybees (Apis mellifera). Apidologie, 39, 436-445.

Morse, R. A., \& Flottum, K. (1997). Honey Bee Pests, Predators and Diseases. Third Edition, Medina, Ohio, USA: A.I. Root Company.

Muz, M.N. (2008). Bal arılarında ani koloni sönmesi. Türkiye Parazitoloji Dergisi, 32(3), 271-275.

Porrini, M.P., Fernandez, N.J., Garrido, P.N., Gende, L.B., Medici, S.K., \& Eguaras, M.J. (2011). In vivo evaluation of antiparasitic activity of plant extracts on Nosema ceranae (Microsporidia). Apidologie, 42, 700-707.

Shimanuki, H., \& Knox, D.A. (2000). Diagnosis of Honeybee Diseases, Agriculture Handbook No. AH- 690. U.S. Department of Agriculture., $61 \mathrm{pp}$.

Şengezer, E., \& Göngör, T. (2008). Esansiyel yağlar ve hayvanlar üzerindeki etkileri. Lalahan Hayvancilık Araştırma Enstitüsü Dergisi, 48(2), 101-110.

Uygur, Ş. Ö., \& Girişgin, A. O. (2008). Bal arısı hastalık ve zararlıları. Uludağ Arıcılık Dergisi, 8(4), 130-142.

Yılmaz, F., Öztürk, S.H., Kuvancı, A., Kayaboynu, Ü., Karataş, Ü., Kaya, S., Derebaşı, E., \& Buldağ, M. (2018). Doğu Karadeniz Bölgesinde Nosema apis ve Nosema ceranae'nın Epidemiyolojisi. Arıcılık Araştırma Dergisi, 10(2), 34-44.

Zeybek, H. (1991). Arı Hastalıkları ve Zararlıları, Tarım ve Köyişleri Bakanlığı Hayvan Hast. Araşt. Enst. Md., Etlik, Ankara. 
